\title{
Characterization of Rainwater Drainage Infrastructure in the City of Lomé (Togo, West Africa)
}

\author{
Kodjovi Senanou Gbafa, (PhD student) \\ Ecole Nationale Supérieure d'Ingénieurs Université de Lomé, Togo \\ Sonnou Tiem, (MC) \\ Ecole Nationale Supérieure d'Ingénieurs Université de Lomé, Togo \\ Kouami Kokou, (Professor) \\ Faculté Des Sciences Université de Lomé, Togo
}

Doi: 10.19044/esj.2017.v13n30p478 URL:http://dx.doi.org/10.19044/esj.2017.v13n30p478

\begin{abstract}
Despite Togo government's efforts to maintain and expand its storm drainage networks, urban flood disasters remain recurrent. Beyond Shallow zones occupation for construction and climatic causes, it is essential to circumscribe the determinants linked to infrastructure. Based on the inventory and characterization of rainwater drainage infrastructure, this study is a contribution to the reduction of flood risk in the city of Lome in Togo.

Surveys were conducted on rainwater drainage works of the 172 paved roads in Lome. A sample of each network group is selected by considering the areas of recurring hazards and broadest catchment areas in the city for the evaluation of their structural and functional states according to the readapted VIZIR method. The relationship between these two states was computed using multiple correspondence analysis (MCA). This study reveals notable insufficiencies in rainwater drainage management in the city, expressed by the existence of roads built without drains, gutters without outlets, and open gutters and makeshift trenches built by the population. Functionally and structurally, almost all the structures are constructed of reinforced concrete. The most cracked are the mainly open pit $(92.02 \%)$ works of the lagoon complex. The retention basin network includes 36 retention ponds 18 of which are interconnected, 11 drained by gravity and 4 by pumping. The latter are inherently hazardous insofar as pumping energy is not guaranteed. The MCA has shown that the network of piping related to the retention ponds are in similar conditions, and that generally, the closed gutters are not cracked while the open gutters are cracked.
\end{abstract}

Keywords: Flood, rainwater drainage infrastructure, Lome, Togo 


\section{Introduction}

Today, global changes are manifested in the climate domain by extremes with ever-increasing violence. In Togo, as in most countries in West Africa, the most noticeable manifestations of these changes are prolonged droughts, floods, high winds and intense heat. (Sheikh, et al., 2007). These hazards affect agriculture, biodiversity, population health (epizootics, malaria, cholera, dysentery, etc.) and human settlements (road and rail infrastructure, sewage works, dams, buildings, etc.) (Wade et al., 2009, Klassou, 2011, Sighomnou et al., 2012, CEA, 2015).

Floods are by far the main threat to human settlements in Togo (Klassou, 2014, MERF, 2013), especially since the current climate trend is towards increasing annual temperatures and rainfall, accompanied by seasonal disturbances (Paturel et al., 1998; GIEC, 2007). More than one and a half million people are affected by floods each year in Africa (Radojevic, 2002). West Africa has experienced an increase in floods during recent years. In 2007, 2.6 million people were affected, causing several losses of life (Wade et al., 2009).

In Togo, about 60 urban and rural floods were recorded between 1925 and 1992, causing material damage and loss of life (Sodogas and Gomados, 2006). The years 2007 and 2008 were marked by floods with disastrous social and economic consequences for the country (PANA, 2008). The situation deteriorated considerably in 2008 with the destruction of several bridges that crippled all economic activities between Togo and the countries of the hinterland (Gbafa, 2010).

Since 2008, Lomé, the capital has become the theater of recurrent floods. Beyond the natural vulnerability of the city and its surroundings to flooding due to its geomorphology (Rossi. 1985; Blivi. 1993, Gnongbo. 1996, Adjoussi. 2008, MERF, 2014), one of the main causes of the floods is poor urban planning. Indeed, urbanization and the development of peri-urban areas (covered with asphalt, concrete, or other impermeable materials) leads to waterproofing of soils and consequently an increase in volumes and flow rates (Chocat, 1989, Jousseaume et al., 2004). Between 1970 and 1981, the urban area of Lomé grew from 1,900 ha to 6,100 ha (an increase of $221 \%$ in 12 years), reaching nearly 9,000 ha in 2014 (Marguerat, 1986, DGH, 2004, MERF. 2016)). The urban area of the Lomé town is now almost totally saturated (only $4.22 \%$ of plot sizes of 600 square meters are unbuilt (MERF. 2014)). Currently, the Lome agglomeration is developing well beyond the perimeter of the town (DGH, 2004), without any preliminary remedial development plans being put in place. Thus many natural depressions are systematically inhabited, causing very severe and recurring flooding problems in large parts of the town. 
The flooding problem in Lomé could be solved by the establishment of an adequate regularly maintained and periodically renewed sanitation system. Indeed, sanitation facilities play an important role both in rainwater drainage and organization of relief (Atta, 2000). Defects in the system are often a source of flooding (Tuo, 2009). This situation raises the following questions: what are the characteristics of the rainwater management works in the city of Lomé and what is their state of performance?

This study aims primarily to help reduce flood risk in Lome. Specifically, the aim is to (i) map the current rainwater drainage works and (ii) characterize the storm drainage networks in the city. This will allow to know their level of service in rainwater drainage with a view to make appropriate decisions for the prevention of flood disasters.

\section{Methodology}

\subsection{Study area}

The city of Lomé is located in the extreme south-west of Togo (Fig. 1). It extends along the coast of the Gulf of Guinea westwards to the Ghana border. Lome is thus, a border town that covers an area of nearly 90 $\mathrm{km}^{2}$ (Kiwix, 2012, Adjoussi, 2015).

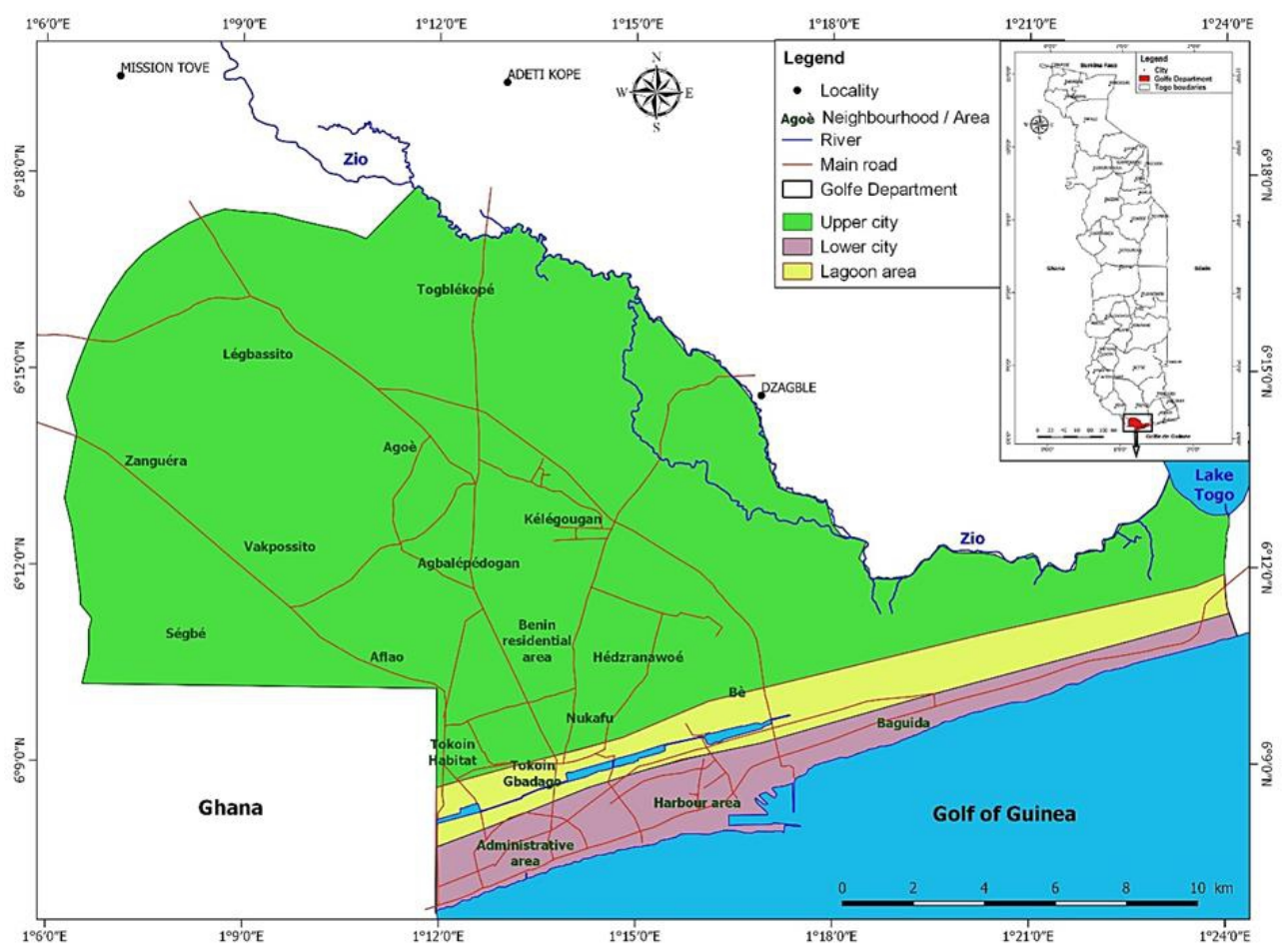

Fig. : 1 Study area 
Lomé enjoys a Guinean subequatorial coastal climate (Aubréville 1949, Edjame, 1992 Adjoussi, 2000) characterized by two rainy seasons (March / April to July and September to November), and two dry seasons (in August then between November and February). Lomé is the part of Togo with the least rainfall ( 800 to $900 \mathrm{~mm}$ of rain per year). The average humidity exceeds $75 \%$. The average monthly minimum values range from $57-58 \%$ during the dry season and $71-73 \%$ during the rainy season (Edjame, 1992, Adjoussi, 2008). The maximum average temperature is $30.7^{\circ} \mathrm{C}$ in the afternoon, and the average minimum $23.1^{\circ} \mathrm{C}$ in the morning. From south to north, the city consists of the three zones (Edjame, 1992 Adjoussi, 2008):

- Lower town: located between the sea and the lagoon, it is an ancient flat dune cordon with altitudes between 2 and $5.5 \mathrm{~m}$ above sea level. It is to the historical heart of Lomé.

- The lagoon zone: located about $2.5 \mathrm{~km}$ from the seafront, it extends in places over a width of about $200 \mathrm{~m}$. The lagoon zone is composed of an equilibrium channel and 3 lakes (West Lake, East Lake and Lake Bè).

- Upper town: this is the plateau area to the north of the lagoon, rising to 35 $m$ altitude. It is limited in the northeast by the Zio River and to the west by the Ghana border, (Adjoussi, 2008).

\subsection{Data collection}

The inventory consisted of systematically recording all the storm water works on the paved roads in Lomé. These are boulevards, avenues, streets and non-denominated roads. The length of the section of each track with or without a sewer is measured using a roller (topometer). According to CIEH (1984) and DGH (2004), the management of storm water in Lomé is made by three types of sewerage networks. These include networks with retention basins, networks of piping and lagoon networks. Each network is composed of primary, secondary and tertiary works. For each network, the rainwater sewerage works identified in the field were noted as present / absent. The chosen descriptors are: the construction material (Concrete / Masonry), the position of the structure with respect to the track and the direction of circulation (left / right lateral, and transverse), the cover of the channels (open / closed). The geographical coordinates of the retention ponds encountered were recorded using a GPS.

\subsection{Characterization of storm water works}

For the characterization of storm water works in Lomé, one example of a sewage network was chosen for each type of network, considering the recurrent flood hazards and the largest catchments in the city (DGH, 2004). For networks with retention basins, the Agbalépédogan network was retained. Among the structured networks, the network of the Residence of 
Benin was chosen. For the lagoon networks, the network of the Tokoin Gbadago district was the subject of the characterization.

The structural and functional nature of each selected network were evaluated using the readapted VIZIR method. VIZIR is a method of evaluating, qualifying and prioritizing a road network of flexible pavements by computer. The visual condition of the roadway is characterized by the type of degradation, its severity and its extent. VIZIR takes into account two types of degradation, structural and functional degradation. These types of degradation have been adapted for the purposes of this study. For each, evaluation is carried out according to a gravity scale of 1 to 4 (Autret and Brousse, 1994, Charbonnier and Tarel, 2008). Thus, the nature of structural degradation is determined on a scale of 1 to 4 according to the degree of cracking of the structures $(1=$ Not Cracked, $2=$ Cracked, $3=$ Very Cracked, $4=$ Broken). The functional status of the structures is also expressed on a scale of 1 to 4 ( 1 = not silted, $2=$ low to medium silted, $3=$ Very silted, $4=$ obstruction). For each work, the geometric characteristics (length, section and depth) were determined using a topometer and a plumb line.

\subsection{Data analysis}

The data collected were processed using the R 3.4 software ( $\mathrm{R}$ core team, 2017) and the Microsoft Excel spreadsheet. Rainwater drainage works have been grouped by category. For each category, the occurrence frequency was calculated. The number of lanes that house and / or are connected to these structures was determined, along with the cumulative length of each structure. Multiple correspondence analysis (MCA) was also performed to describe the relationship between the structural and functional states of the structures of the different networks studied. Mapping of the different retention basins was done using the QGIS 2.18.12 software.

\section{Results}

\subsection{Typology of the sanitation works in Lome}

The fieldwork allowed a total of 172 paved roads to be surveyed and four (04) different networks of storm sewerage works to be identified in the city, contrary to what was identified during the development of the DGH in 2004. That is to say, in addition to the networks of retention basins, lagoon complex networks and networks of piping, the study identified a fourth type of network made of channels without an outlet. They had a very important role in the occurrence of floods by accumulating and directing rainfall water towards talwegs or natural depressions. 


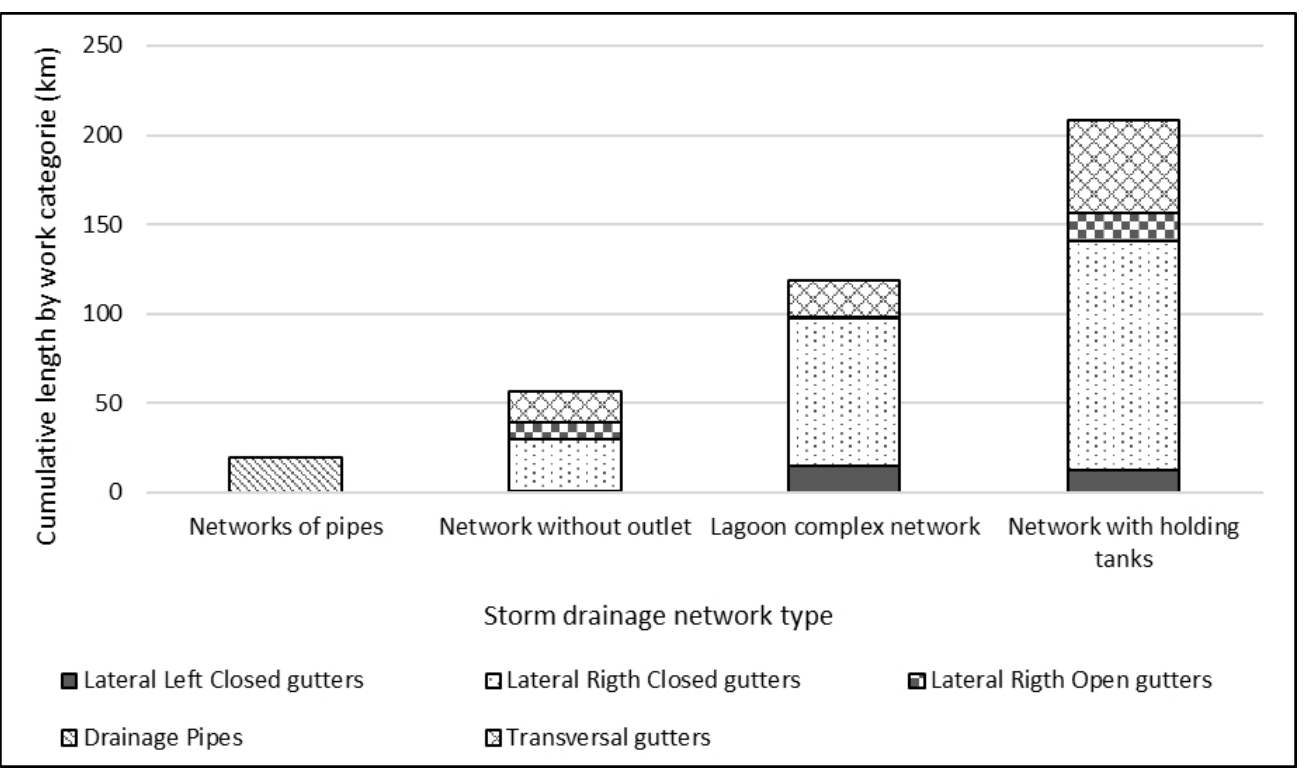

Fig. : 2 Different types of rainwater drainage networks

Among the structures encountered, those of the structuring network are the least represented, with a cumulative length of $19.60 \mathrm{~km}$, that is $4.87 \%$, followed by gutter networks without an outlet (cumulative length of 56.28 $\mathrm{km}$, ie $14.00 \%$ ), and lagoon complex networks (cumulative length of 118.44 $\mathrm{km}$, or 29.46\%) (Fig. 2). The closed right lateral channels are highly represented in the networks of pipes $(50.78 \%)$ and in the lagoon complex $(69.47 \%)$. The lateral right open channels are not negligible for networks without outlet (16.96\%). Closed left side channels are poorly represented except in the lagoon complex (13\%). The networks of gutters linked to the retention basins are the most represented (cumulative length of $208 \mathrm{~km}$, ie $51.75 \%$ ) (Fig. 2). This type of network is represented at $61.65 \%$ by the closed straight lateral channels and at $7.5 \%$ by the open right lateral channels. The results also show that Lomé has a total of 36 retention basins, half of which are interconnected at a rate of 15 for the Agbalépédogan Aflao - Agoè network and 3 for the Nukafu network. The other half is made up of independent ponds, 7 of which have no outlets and 5 are equipped with pumping outflow systems (Fig. 3). The overflow of the 6 others is evacuated by gravity towards the lagoon or the river Zio. 


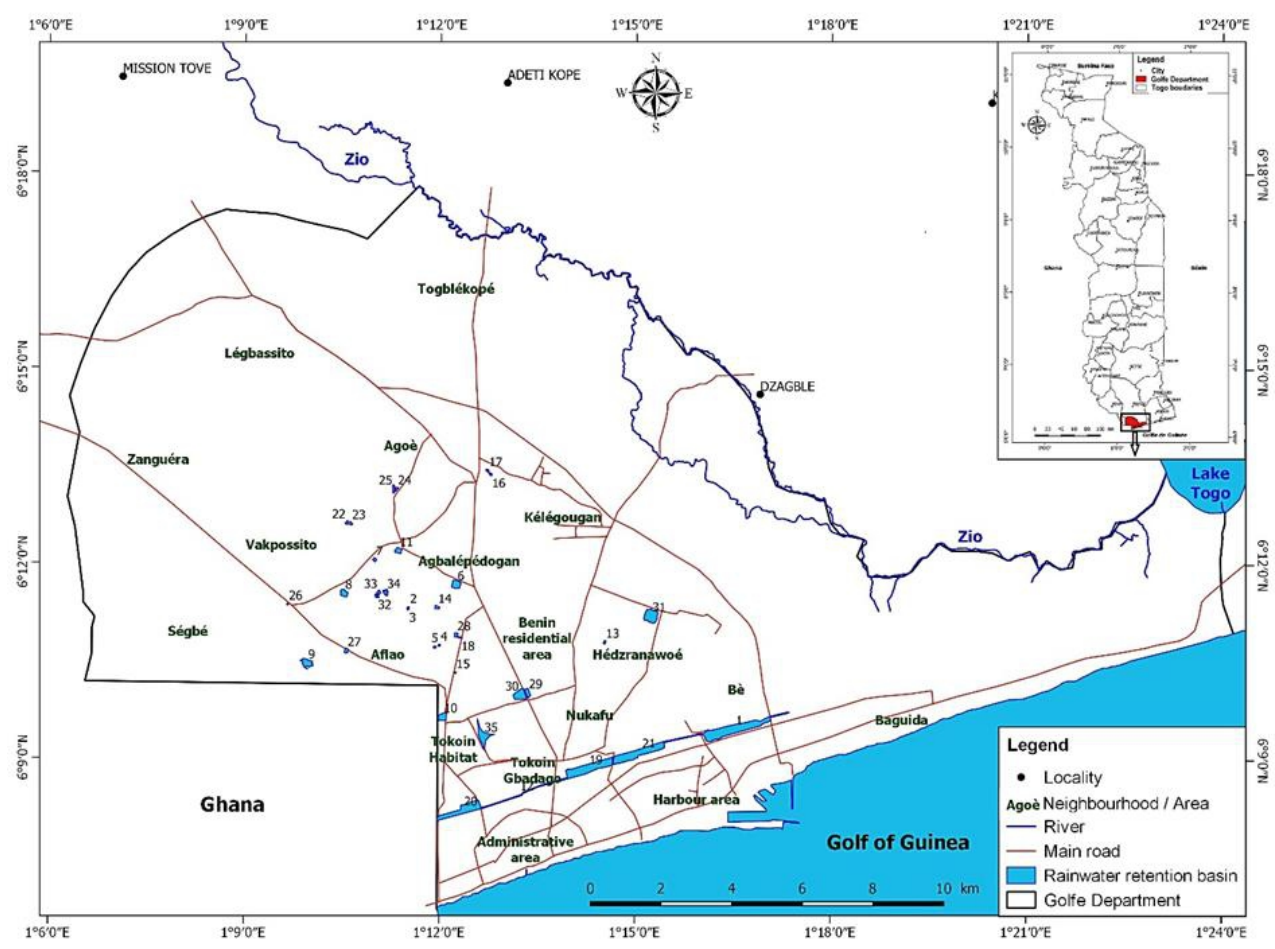

Fig. : 3 : Distribution of retention basins encountered in Lomé

\subsection{Characteristics of the sanitation works in Lomé}

\subsubsection{Structuring networks in the Benin Residence}

The network of piping at the Residence of Benin has a total of 4981 linear meters of rainfall structures. It consists of primary, secondary and tertiary gutters. The primary pipes cover 1696 linear meters with diameters between 500 and $600 \mathrm{~mm}$, secondary pipes with a length of 2042 linear meters and diameters between 200 and $400 \mathrm{~mm}$, and finally small gutters which make up the tertiary part with a length of 1243 linear meters. This network also includes 64 manholes and 15 filtering wells. Structurally, the primary conduits of this network are moderately cracked $(20.17 \%$ cracked, $11.73 \%$ very cracked and $68.10 \%$ uncracked). The secondary pipes run along streets within the residence. They are mainly cracked (57.54\%) and have only $34.18 \%$ of uncracked structures. The gutters are for the most part open (39\%) and comprise only $33.81 \%$ of uncracked structures against $55.27 \%$ cracked and $10.92 \%$ very crack (Fig. 4 ). 


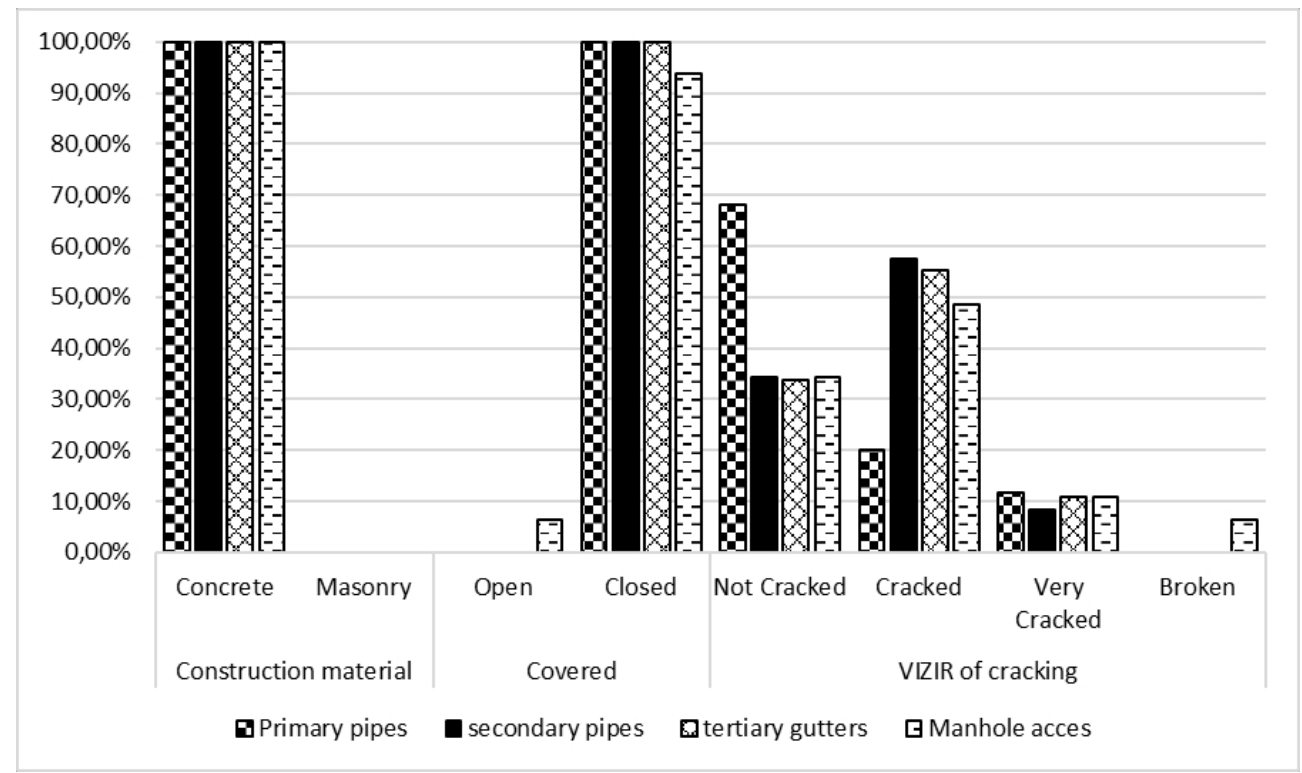

Fig. : 4: Characteristics of the network of piping

\subsubsection{Network with retention basin: case of the Agbalépédogan network}

The Agbalépédogan network with retention basin extends over 89457 linear meters entirely constructed in reinforced concrete. The network has 15 interconnected holding tanks, 11 of which are drained by gravity, while the other 4 are equipped with pumping systems. The overflow is drained from a downstream basin to an upstream basin step by step.

The mostly closed primary culverts $(69.42 \%)$ extend over 6592 meters. The open part corresponds to the trapezoidal channel, which is 2016 meters long and has a section varying from $2.20 \mathrm{~m}^{2}$ to $5.75 \mathrm{~m}^{2}$. Their VIZIR state shows that these channels are free from silting (100\%) and are in a very good structural condition (91.26\%) (Fig. 5). The secondary gutters of the grid have a length of 67576 linear meters and are $95.47 \%$ covered. They are also free from silting (100\%) and have an intact structure (93.93\%). Their section varies from 0.57 to $1.2325 \mathrm{~m}^{2}$. The tertiary gutters cover a total distance of 12485 linear meters with a section varying from 0.3 to $0.85 \mathrm{~m}^{2}$. Covered at $88.96 \%$, their VIZIR state is identical to that of the primary and secondary gutters. 


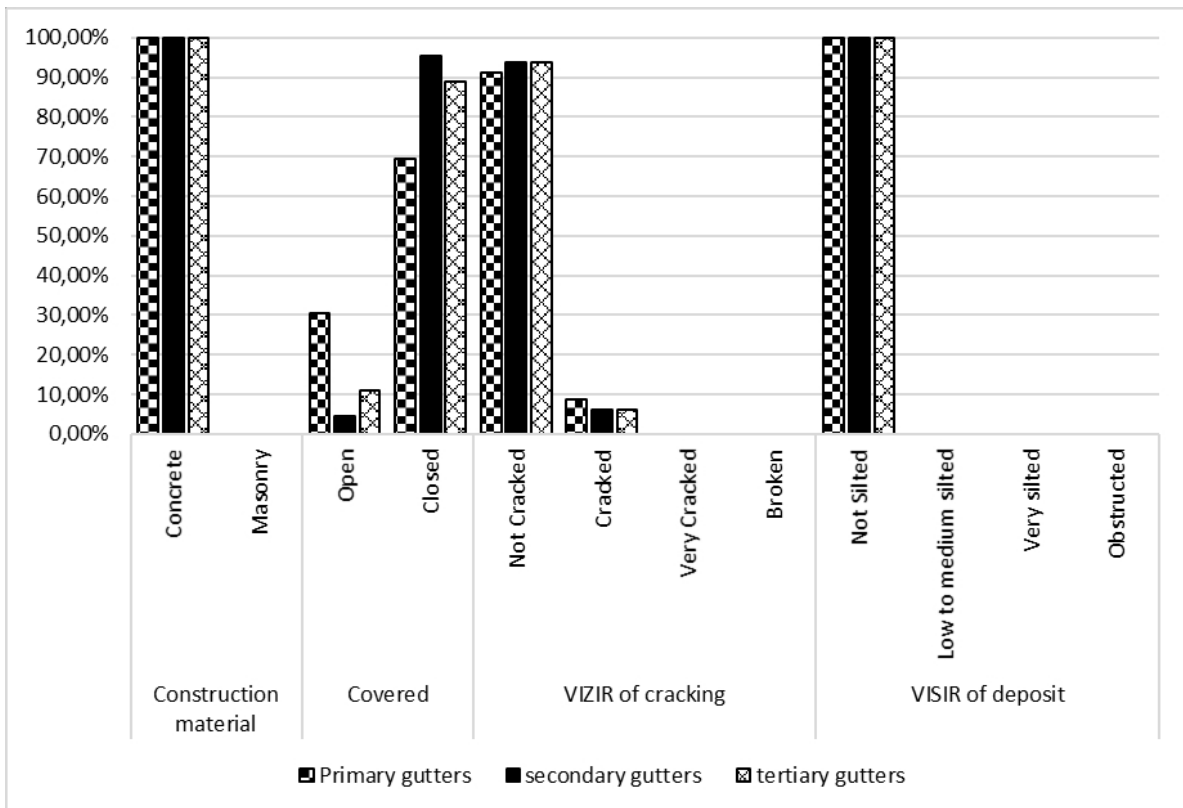

Fig. : 5: characteristics of rainwater network having retention basins

\subsubsection{Lagoon complex of Tokoin Gbadago district}

The rainwater drainage network of the Tokoin Gbadago lagoon complex has a total length of 4962 linear meters. Its primary gutters, entirely constructed of reinforced concrete, have a total linear length of 1203 meters and are predominantly open pit $(92.02 \%)$. The closed area $(7.98 \%)$ is only used as vehicle crossings at intersections. Their section varies from 1.575 to $6.75 \mathrm{~m}^{2}$. Their VIZIR state shows that $6.23 \%$ of these channels are completely broken, $30.74 \%$ cracked to very crack and $63.34 \%$ are in good condition (Fig. 6). In terms of silting, only 56.94\% are free from sand deposits, $21.28 \%$ are silted, $12.64 \%$ are highly silted and $9.14 \%$ are completely blocked. The secondary gutters have a length of 1274 linear meters and are also entirely constructed of reinforced concrete. The portion covered by these secondary gutters represents $55.42 \%$ and is found along the paved roads, while the open area $(44.58 \%)$ is found in the neighborhood alleys. Their section varies from 0.57 to $1.2325 \mathrm{~m}^{2}$. The VIZIR state of these gutters shows that only $55.34 \%$ are in good condition; the rest is either completely broken $(10.20 \%)$ or cracked $(34.46 \%)$. These gutters are predominantly silted $(61.93 \%)$ or obstructed $(17.66 \%)$. Field observations revealed that the cracking of the primary and secondary gutters is due to poor implementation of the concrete or the onset of aging. The degree of silting is due to the low slope and lack of maintenance of the structures. The tertiary gutters cover a total distance of 2,485 linear meters with section varying 
from 0.3 to $0.85 \mathrm{~m}^{2}$. Covered at $44.58 \%$, they are the most cracked and the most silted (only $35.09 \%$ are in good condition and free from sand deposits). It should be noted that the primary and secondary gutters are built by the government while the tertiary gutters that are made of masonry are built by the inhabitants of the neighborhoods.

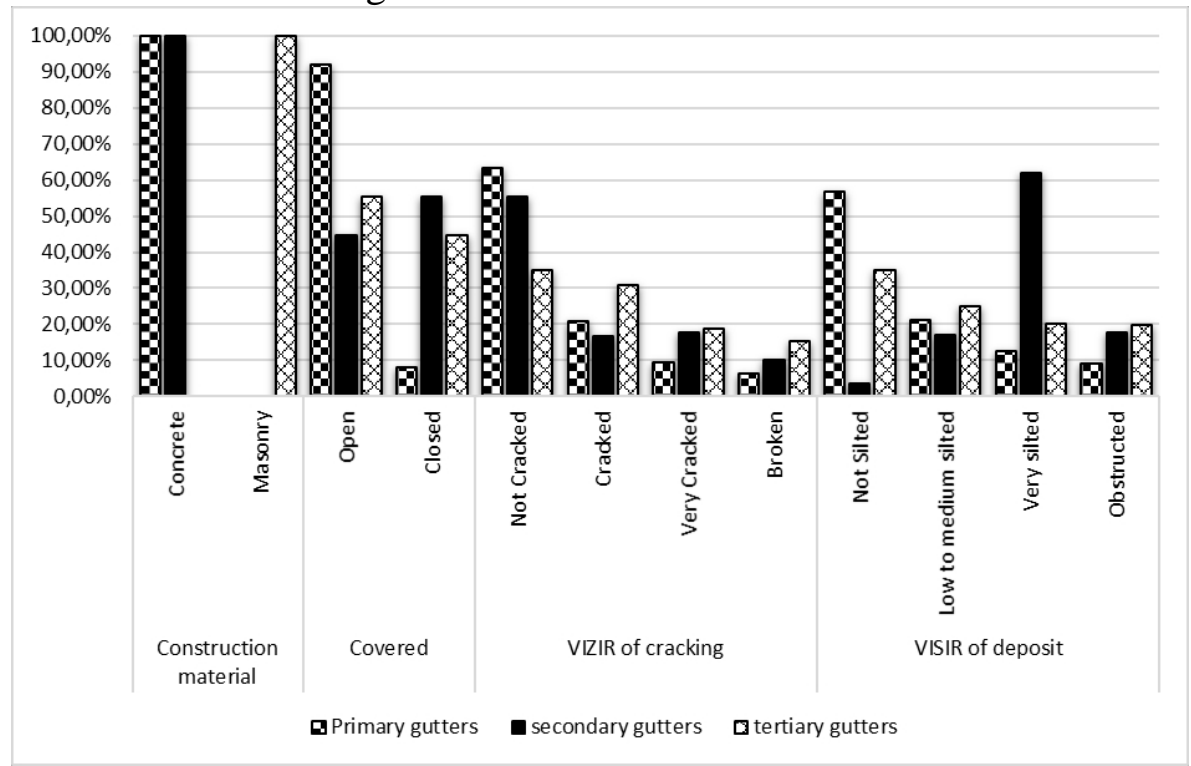

Fig. : 6: Characteristics of the lagoon complex rainfall network

\subsubsection{Relationship between structural and functional states}

Multiple correspondences analysis carried out to describe the relationship between the structure of the gutters and their states shows that the networks with retention basins and network of piping are structurally and functionally similar (Fig. 7). In fact, these two types of network generally have gutters made of reinforced concrete. These gutters are in most cases closed, not cracked to weakly cracked and not silted. The lagoon complex differs from the first two types of network by the presence of masonry channels in addition to those made of reinforced concrete. In this network, the gutters are open, very cracked, broken, consequently very silted and obstructed (Fig. 7). 


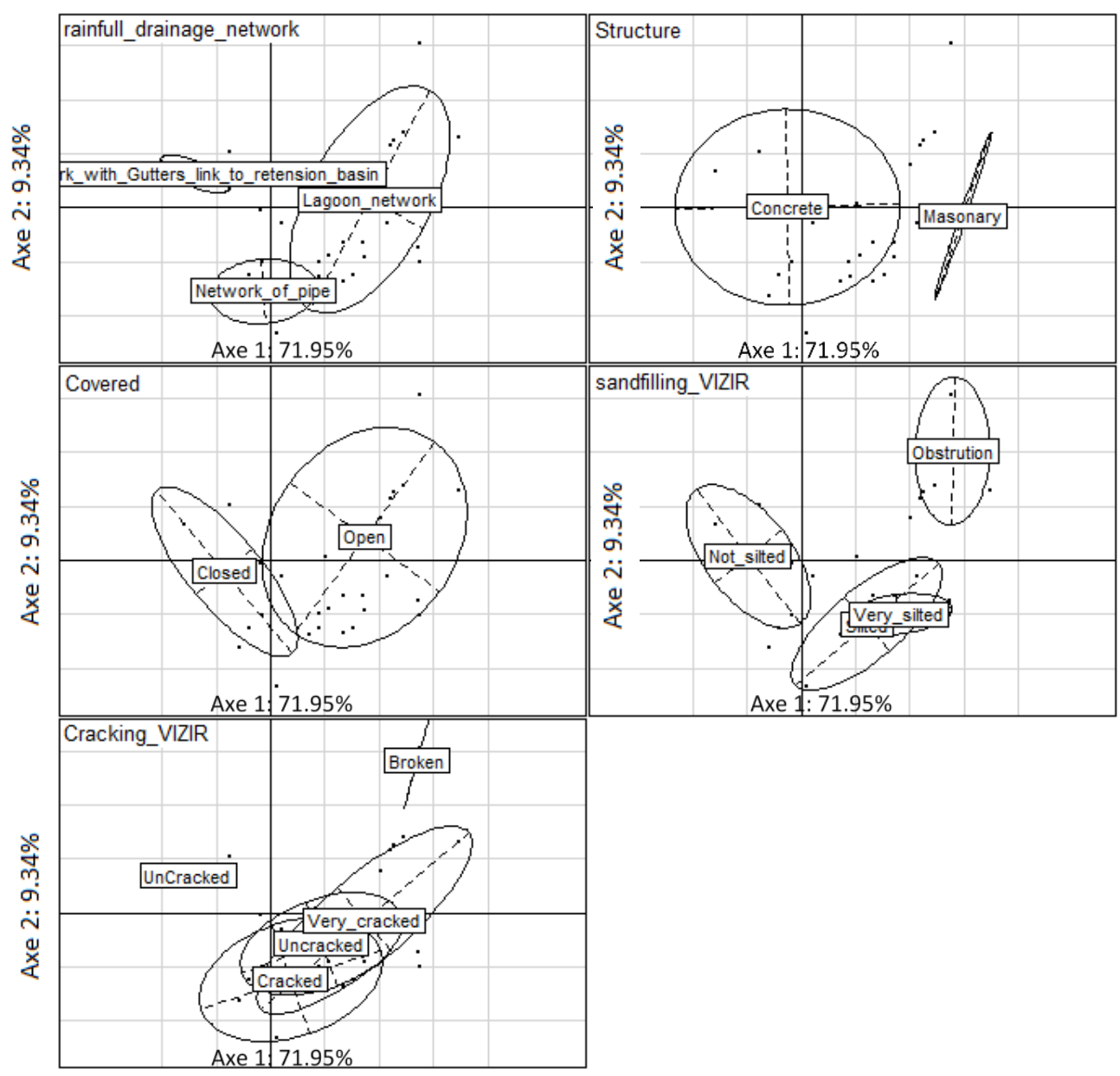

Fig. : 7 : relationship between the structural and functional state of drainage networks

\section{Discussion}

This study provided insight into the various sanitation facilities and their performance degree in storm water drainage with a view to making appropriate decisions for the prevention of flood disasters. The results show that the sewage works in the city of Lome are made up of gutter networks linked to retention ponds, lagoon network gutters, networks of pipes and outflow networks. There is a notable lack of adequate sanitation facilities in Lome, which explains the high proportion of structures built by the population (gutters built of masonry) and gutter networks of with no outlets $(14.00 \%)$. thus, making streets and natural depressions evacuation channels for storm flows. This situation poses a serious problem for riverine populations concerning storm water management. According to Atta (2000), sanitation and drainage systems are very important elements to consider in 
the management of storm water in urban areas. For this author, the inadequacy of sanitation facilities accentuates floods with their harmful effects. The consequences of flooding are sometimes dramatic. They caused 500 deaths in Mozambique in 2008 (United Nations, 2009) and affected more than 700,000 people in September 2009 in 16 West African countries.

The most affected being Burkina Faso, Senegal, Ghana, Niger and Togo (Niassé et al., 2004, Dasylva, 2009, Di-Baldassarre et al., 2010). In Togo, floods have been recurrent in recent years in the large cities. Research carried out by (PNDA, 2010) indicates that urban floods are generally caused by bad occupation of space due to a lack of knowledge of urban hydrographic networks and inappropriate infrastructure and wrong design of the sewage and storm drainage works. Thus, it appears that a durable solution to flooding requires a good understanding of the hydrological and hydrogeological functioning of urban catchments (Diouf, 2011). This requires not only good mapping of basins but also, a detailed study of precipitation at infra-hour scales, since the process of water stagnation is not only a matter of quantity but also of intensity (Van Tuu, 1981, Wallez, 2010). Precipitation, temperature and hygrometry play an essential role in the presence of diseases such as malaria or yellow fever (Dasylva, 2009, Diaz et al., 2009, Wallez, 2010). The multiplicity of extreme climatic events could prolong the development periods of the insects carrying these diseases. In 2009, Tuo's work showed that malaria accounts for $25.87 \%$ of illnesses due to lack of sanitation.

Floods are characterized by intense run-off and overflowing of natural depressions, causing erosion, creating ditches, exposing existing sanitation infrastructure and degrading streets (Lebel and Ali, 2009; Bodian et al., 2011, Bodian, 2014, Descroix et al., 2015, Diop et al., 2016). Erosion of the foundations of houses built on slopes may cause them to collapse. It also affects roads through the formation of ditches, and makes access to the inner neighborhoods difficult (Kassi, 2004).

The small proportion of gravity drainage retention basins (11 out of 36), coupled with the presence of pumping equipment on retention ponds ( 7 of 36), shows a serious flaw in design. This is confirmed by the DGH (2004), which states that the normal tidal range between the minimum level (set by the water table) and the maximum level is less than one meter. In addition, the use of electrical pumping equipment for water reservoirs during the rainy season may increase the risk of flooding in areas with ponds in the event of a power outage, as power cuts in Lomé are almost automatic in case of thunder. With regard to the capacity of the drainage system in the basins, studies carried out as part of the updating of the DGH have shown that it has reached its saturation level due to significant deterioration in the structure itself. This often results in flooding of the basins and the riverine areas. 
According to Desbordes and Bouvier (1990), only water storage facilities, such as rainwater reservoirs, are the most efficient. This situation is also noted in Lome, where the networks linked to retention basins are siltfree and structurally efficient. As regards the structures of the networks of piping and the lagoon complex, they are mostly cracked, broken and / or silted. These runoff structures are often inoperable for several reasons, including: the lack of maintenance and alternative use of canals by the population (discharge of domestic or industrial wastewater, dumps garbage, etc.). The difficulty of evacuating runoff is a major cause of flooding in urban areas. If sewage systems exist, added rainwater causes the capacity of urban sanitation infrastructure to be exceeded (Laganier, and Scarwell, 2004).

For the urban community of Lome, sanitation facilities, covered or open, have insufficient drainage capacity, in particular because silting decreases their section and therefore flow through the networks and outlets are clogged by sand barriers and solid waste. The degree of urbanization and the parameters of environmental management (waste management) are essential factors to consider. Abdoulaye (1998) also observed the presence of waste in the structures in the city of Parakou in Benin. His work showed that $45 \%$ of the drainage studied in Parakou (Benin) were clogged, $15 \%$ of which were deliberately blocked by neighbors. These results are confirmed by the studies by Desbordes and Bouvier (1990) who, working on urban rainwater sanitation in West Africa, have also shown that open-pit water works are gradually filled with various wastes by users who are often unaware of the problems they create. These authors have also shown that, in addition to deposits of waste, many agglomerations have a high level of solid transport due to wind or hydraulic erosion of large surfaces without vegetation which isn't easy to control. Alain (1996) argues that the hydraulic dysfunction of drainage works is caused in most cases by solid waste and hydraulic erosion. These situations cause difficult rainwater flow and consequently the stagnation of rainwater in clogged gutters. This increases the risk of flooding, degradation of the environment and living conditions. This situation also promotes the proliferation of pathogens and increases the occurrence of water-related diseases. The populations of the flooded areas are exposed to these diseases (diarrhea, cholera, malaria ...) affecting their income. According to WHO (2004), flooding is a destabilizing element of a healthy environment, a source of health problems and above all a proliferation of many life-threatening human diseases. Similarly, Diaz et al. (2009), Dasylva (2009) and Wallez (2010) report that floods are in most cases responsible for diseases such as malaria or yellow fever. According to these authors, the multiplicity of extreme climatic events could prolong the development periods of the insects carrying these diseases. In 2009, Tuo 
found that malaria constitutes $25.87 \%$ of the diseases related to flood and the lack of sanitation.

\section{Conclusion}

The aim of this work was to carry out a diagnostic analysis of the sewerage network in the city of Lomé. It enabled i) to inventory and ii) to evaluate the structural states and operations of the sanitation network. It is apparent that in Lome, sanitation works are being built or rehabilitated, but their density remains low and their level of service always below average. This lack of adequate rain drainage infrastructure, coupled with a chronic lack of maintenance of the existing installations, increasingly results in critical flooding, leading to major property damage, the proliferation of water-borne diseases and loss of life.

The problem of rain-fed sanitation must be posed in financial and material terms, but also in geomorphological and edaphic terms. In other words, it is necessary to include geographical factors including problems of demographic and urban growth, natural hazard zones and the quality of development in all sanitation programs. In addition, all actors (population, economic agents and public authorities ...) must be involved in decisionmaking and in various programs to raise awareness, to maintain and to build sanitation infrastructure for the rational management of rainwater.

\section{References:}

1. Adjoussi, P. (2000). Changements climatique global. Evaluation de l'évolution des paramètres climatiques au Togo. Département de géographie, Université du Bénin, 121p

2. Adjoussi P. (2008), Vulnérabilité des systèmes côtiers à l'élévation du niveau marin entre la Volta et le Mono dans le golfe du Bénin (Afrique de 1'Ouest). Thèse de doctorat d'Université. Université de Lomé, 416 p.

3. Alain, M. (1996). L'assainissement des eaux pluviales en milieu tropical subsaharien. Dossiers techniques, programmes en eau et assainissement. PNUD, Banque Mondiale, (167 p).

4. Aubréville, A. (1937). Les forêts du Dahomey et du Togo. Bulletin du Comité d'études historiques (29:1-113).

5. Blivi A., (1993), Géomorphologie et dynamique actuelle du littoral du Golfe du Bénin (Afrique de l'Ouest). Thèse de doctorat, Université Michel de Montaigne, Bordeaux, 458 p.

6. Bodian, A., Dacosta, H., \& Dezetter, A. (2011). Caractérisation spatio-temporelle du régime pluviométrique du haut bassin du fleuve Sénégal dans un contexte de variabilité climatique. Physio-Géo (5, 116-133). 
7. Bodian, A. (2014). Caractérisation de la variabilité temporelle récente des précipitations annuelles au Sénégal (Afrique de l'Ouest). Revue Physio-Géo (8, 297-312).

8. Commission Economique des nations unies pour l'Afrique (2015). Rapport d'évaluation sur l'intégration et la mise en œuvre des mesures de réduction des risques de catastrophe au Togo, (76 p). Addis Ababa .

9. CIEH (1985). Séminaire International sur l'assainissement pluvial en Afrique de l'ouest et du Centre. Comité Interafricain d'études hydrologiques, (p. 56). Ouagadougou.

10. Cheikh, M. A., Ozer, P., \& Ozer, A. (2007). Risques d'inondation dans la ville de Nouakchott (Mauritanie). Géo-Eco Trop.

11. Chocat, B. (1990). La crue de l'Yzeron du 29 avril 1989, premiers éléments d'analyse. Rapport interne, (pp 3). INSA Lyon-France.

12. Dasylva, S. (2009). Inondations à Dakar et au Sahel, Gestion durable des eaux de pluie.

13. Etudes et Recherches, $n^{\circ}$ 267-268-269, enda Editions, Dakar, 259 p.

14. Desbordes, M., \& Bouvier, C. (1990). Assainissement pluvial urbain en Afrique de l'ouest. Modélisation du ruissellement. Rapport final, (408p).

15. Descroix, L., Diongue, Niang A., Panthou, G., Bodian, A., Sane, Y., Dacosta, H., Malam Abdou, M., Vandervaere, J.-P., \& Quantin, G. (2015). Evolution récente de la pluviométrie en Afrique de l'Ouest à travers deux régions : la Sénégambie et le bassin du Niger moyen. Climatologie, (Pp. 25-43).

16. DGH (2004). Plan Directeur d'Assainissement de la ville de Lomé. Rapport définitif, (286 p).

17. Diaz Olvera, L., Plat, D., Pochet, P., \& Sahabana, M. (2009). Changement climatique, pauvreté et transport dans les villes du Sud du Sahara. XLVIème colloque de l'Association de Science Sousrégionale De Langue Française (14 p). Clermont-Ferrand, France. .

18. Di-Baldassarre, G., Montanari, A., Lins H., Koutsoyiannis, D.,Brandimarte, L., \& Bloschl, G. (2010). Flood fatalities in Africa: from diagnosis to mitigation. Geophys. Res.

19. Diop, L., Bodian, A., \& Diallo D. (2016). Spatiotemporal trend analysis of the mean annual rainfall in Senegal. European Scientific Journal, (Pp. 231-245).

20. Diouf, R. N. (2011). Etude hydro-pluviométrique des bassins versants urbains de la presqu'île du Cap-Vert. Thèse de doctorat de 3ème cycle, Département de Géographie, Université Cheikh Anta Diop de Dakar, 248 pages. 
21. Edjame, K. S. et al (1992), Changement Climatique global : Les syndromes perçus au Togo. in Actes des journées Scientifiques de l'U.B., Presse De l'U.B. Lomé pp. 169-180.

22. Gbafa, S. K. (2010). Impacts de la réduction du niveau de service des infrastructures routières: Cas du pont de LANGABOU sur la RN 1 au Togo. Mémoire de DEA, Université de Lomé.

23. GIEC (2007). Bilan 2007 des changements climatiques. Contribution des Groupes de travail I, II et III au quatrième Rapport d'évaluation du Groupe d'experts intergouvernemental sur l'évolution du climat, (103 p). Genève, Suisse.

24. Jousseaume, V., Landrein, J., \& Mercier, D. (2004). La vulnérabilité des Hommes et des habitations face au risque d'inondation dans le Val nantais entre législation nationale et pratiques locales. (P. u. Rennes, Éd.) Rennes, France.

25. Kassi, L.P. (2004). Site urbain, assainissement et risques naturels à Grand-Bassam. Mémoire de Maîtrise, Université de Cocody, (106 pages).

26. Klassou, K.S. (2011). L'urbanisation et l'assainissement pluvial au Togo. Revue de géographie tropicale de l'environnement, (pp. 4560). Abidjan.

27. Klassou, K.S. (2014). L'influence humaine dans l'origine et la gravité des inondations au Togo : cas de l'aménagement de l'espace dans la grande banlieue nord de Lomé (Togle-Adetikope) Revue de géographie tropicale de l'environnement, (pp. 3-15). Abidjan.

28. Laganier, R., \& Scarwell, H. J. (2004). Risque d'inondation et aménagement durable des territoires. Presse Universitaire $d u$ Septentrion, $(226 \mathrm{p})$.

29. Lebel, T. \& Ali, A. (2009). Recent trends in the central and western Sahel rainfall regime (1990-2007). Journal of Hydrology, (Pp. 5264).

30. Marguerat, Y. (1986). Dynamique sociale et dynamique spatiale d'une capitale africaine : les étapes de la croissance de Lomé. ORSTOM, (37 p). Cotonou.

31. MERF (2013). Stratégie Nationale de Réduction des Risques de Catastrophes naturelles au Togo. $100 \mathrm{p}$.

32. MERF (2014). Cartographie des zones à risque d'inondation de Lomé et ses environs. Rapport final. Groupement GEOCONSULT GESTER, $26 \mathrm{p}$.

33. MERF (2014). Troisième communication nationale du Togo sur les changements climatiques : Etudes sur les circonstances nationales. Rapport définitif, (166 p). 
34. MERF (2016). Troisième communication nationale du Togo sur les changements climatiques : Etablissement des scénarios climatiques. Rapport définitif, (44 p).

35. Niasse, M., Afouda, A. \& Amani, A. (2004). Réduire la vulnérabilité de l'Afrique de l'Ouest aux impacts du climat sur les ressources en eau, les zones humides et la désertification : Eléments de stratégie sous régionale de préparation et d'adaptation. Sommaire exécutif, (17 p). Royaume-Uni.

36. OMS, (2004). Liens entre l'eau, l'assainissement, l'hygiène et la santé, faits et chiffres. 2p.

37. PANA (2009). Plan d'action national d'adaptation aux changements climatiques. $113 \mathrm{p}$.

38. PNDA (2010). Evaluation des dommages, pertes et besoins de reconstruction post catastrophes des inondations de 2010 au Togo. Rapport final, (39 p).

39. Paturel, J.E., Servat, E., \& Delattre, M.O. (1998). Analyse de séries pluviométriques de longue durée en Afrique de l'Ouest et Centrale non sahélienne dans un contexte de variabilité climatique. Journal des Sciences Hydrologiques, 43(6).

40. Radojevic, b. (2002). Méthode d'évaluation de l'influence urbaine sur le régime des crues d'un bassin versant de $130 \mathrm{Km}^{2}$. Thèse de doctorat Institue national des sciences appliquées. Lyon, France.

41. Rossi, G. (1989), L'érosion du littoral dans le golfe du Bénin : un exemple de perturbation d'un équilibre morphodynamique. In $\mathrm{Z}$. Géomorph. N. F. Suppl-Bd. 73, 139-165.

42. Sighomnou, D., Tanimoun, B., Alio, A., Zomodo, L., Ilia, A., Olomoda, I., Coulibaly, B., Koné, S., Zinsou, D., \& Dessouassi R. (2012). Crue exceptionnelle et inondation au cours des mois d'août et septembre 2012 dans le Niger moyen et inférieur. ABN (11p). Niamey.

43. Sodogas, A.V. \& Gomado, K. (2006). Analyse situationnelle des risques et facteurs de risques potentiels en matière de désastres au Togo.

44. Tuo, P. (2009). Assainissement et gestion de l'environnement dans la commune d'Adjame: le cas de Williamsville (Abidjan). Mémoire de Maitrise, Institut de Géographie Tropicale-Université de Cocody, (140 p). Abidjan.

45. United Nations, (2009). Water in a Changing World. UNESCO, (318 p). Paris.

46. Van, Tuu, (1981). Hydraulique routière. BCEOM, République Française, Ministère de la coopération et du développement, (342 p). France. 
47. Wade, s., Faye, S., Dieng, M., Kaba, M., \& Kane, N.R. (2009). Télédétection des catastrophes d'inondation urbaine: Le cas de la région de Dakar (Sénégal). Journal d'Animation Scientifique (7p).

48. Wallez, L. (2010). Inondations dans les villes d'Afrique de l'ouest: diagnostic et éléments de renforcement des capacités d'adaptation dans le Grand Cotonou. Maîtrise en Environnement, Université de Sherbrooke, Sherbrooke. 